\title{
THÂTT NGHIỆP TĂNG MẠNH DO TÁC ĐỘNG CỦA COVID-19
}

\author{
Phạm Minh Thu, Hoàng Thị Bích Thủy, Trịnh Minh Thúy, \\ Nguyễn Phúc Thư, Nguyễn Thị Thương
}

Đại học Quốc gia Hà Nội

Ngày 14 tháng 2 năm 2022

Preprint DOI: $10.31219 /$ osf.io/hfw78 


\section{A. LỜI Mở ĐẦU}

Vấn đề việc làm và thất nghiệp luôn nhận được sự quan tâm lớn của hầu hết các quốc gia trên thế giới. Thất nghiệp tồn tại ở tất cả các nền kinh tế và chúng có các mức độ khác nhau. Hầu hết các quốc gia đều cố gắng xây dựng các chính sách hướng đển tăng trưởng kinh tế, ổn định các mức giá cho dịch vụ và hàng hóa, cải thiện nguồn cung việc làm và cắt giảm tình trạng thiếu việc làm.

Thế nhưng cho đến nay, đại dịch COVID-19 đã càn quét khốc liệt trên phạm vi toàn thế giới và đang diễn biến rất khó lường tại nhiều quốc gia. Tình hình dịch bệnh kéo dài đã gây ra những tác động tiêu cực không nhỏ đến cả các nền kinh tế lớn như Mỹ, Trung Quốc, Nhật Bản, Liên minh châu Âu,... Tình hình dịch Covid19 ở Việt Nam cũng không ngoại lệ và đang diễn biến hết sức phức tạp (La, 2020; Vuong, Q.H., 2022).

Việt Nam có 1,6 triệu ca mắc trong đó hơn 1,1 triệu người đã khỏi bệnh và hơn 30 nghìn đồng bào tử vong (số liệu của Bộ Y tế tính đến ngày 24/12/2021). Mỗi ngày, số ca mắc COVID-19 lên đến vài nghìn. Ở các thành phố lớn như Hà Nội, Hồ Chí Minh... - nơi tập trung nhiều người lao động và các khu công nghiệp buộc phải tạm dừng hoạt động, thực hiện giãn cách xã hội nghiêm ngặt trong một thời gian nhất định để hỗ trợ phòng dịch. Đồng thời, người dân cũng buộc phải ở trong nhà, không được ra ngoài nếu không có việc gì khẩn cấp. Và một trong những ảnh hưởng lớn nhất từ đại dịch này chính là nạn thất nghiệp - vấn đề nhức nhối của toàn xã hội.

\section{A. PHẦn NộI DUNG}

\section{Khái niềm về thất nghiêp và các thuât ngữ liên quan.}

Thất nghiệp (Unemployment) là tình trạng khi những người đang trong độ tuổi lao động hoặc có khả năng lao động nhưng lại đang trong tình trạng tìm việc làm hay không có việc làm mặc dù thừa khả năng lao động, bằng cấp

Người có việc làm là những người trong độ tuổi lao động đang làm việc trong các cơ sở sản xuất, kinh doanh, văn hóa, xã hội hoặc cơ sở làm việc có tính chất tái nhập cảnh

Lực lượng lao động là một bộ phận dân số đang trong độ tuổi lao động (dân số trưởng thành) thực sự có việc làm, hoặc những người thất nghiệp nhưng đang tìm việc làm

Người trong độ tuổi lao động là những người đã đủ tuổi được Hiến pháp quy định có trách nhiệm và quyền làm việc, quyền lợi lao động

\section{Phân loại thất nghiệp.}

Có nhiều nguyên nhân khác nhau gây nên tình trạng thất nghiệp, nhưng dù là nguyên nhân chủ quan hay khách quan cũng ít nhiều ảnh hưởng đến nền kinh tế- giảm sút kinh tế và đồng thời cũng phần nào gây bất lợi cho người lao động. Hiện nay có thể phân loại tỷ lệ thất nghiệp thành các loại sau tùy thuộc vào đặc điểm, nguyên nhân riêng của từng loại:

A. Phân loại theo lí do: 
- Mất việc: Nhân sự ng bị cơ quan/doanh nghiệp cho thôi việc vì một lý do nào đó và rơi vào tình trạng thất nghiệp.

- Bỏ việc: Đây là hình thức thôi việc do bản thân người đó có điều không hài lòng với đơn vị làm việc của mình nên chủ động xin thôi việc.

- Nhập mới: Lao động mới của thị trường nhưng chưa tìm được việc làm

- Tái nhập: Lao động đã rời khỏi thị trường trước đó, hiện muốn đi làm trở lại nhưng chưa có được vị trí thích hợp.

B. Phân loại theo tính chất

- Thất nghiệp không tự nguyện (involuntary unemployment); là tình trạng thất nghiệp mà ở đó người lao động sẵn sàng đi làm với mức lương hiện hành nhưng không tìm được việc

- Thất nghiệp tự nguyện (voluntary unemployment): là tình trạng thất nghiệp phát sinh do người lao động không chấp nhận những công việc hiện thời với mức lương tương ứng (VD. Sinh viên không đi làm thêm, tập trung vào việc học để có bằng cấp sau đỏ mới tìm kiếm những công việc có mức lương cao hơn)

C. Phân loại theo nguyên nhân

Phân loại theo nguyên nhân thì thất nghiệp được chia thành 3 loại lớn, đó là thất nghiệp tự nhiên, thất nghiệp chu kỷ và thất nghiệp theo lý thuyết cổ điển:

- Thất nghiệp tự nhiên (natural unemployment) là mức thất nghiệp bình thưởng mà nền kinh trải qua, là dạng thất nghiệp không mất đi trong dài hạn, tồn tại ngay cả khi thị trường lao động cân bằng:

- Thất nghiệp cơ cấu (structural unemployment) xảy ra khi có sự mất cân đối về mặt cơ cấu giữa cung và cẩu lao động. Nguyên nhân có thể là do người lao động thiếu kỹ năng, hoặc sự khác biệt về địa điểm cư trú.

- Thất nghiệp tạm thời (frictional unemployment) là thất nghiệp do người lao động bỏ việc cũ tìm việc mới, có sự thay đồi về địa lý hoặc những người lao động mới gia nhập hay tái gia nhập lực lượng lao động cần có thời gian để tìm việc làm.

- Thất nghiệp thời vụ (seasonal unemployment) là tình trạng người lao động không có việc làm trong một khoảng thời gian nhất định trong năm (VD: Nhân viên resort, công viên nước, trượt băng, trượt tuyết thường sẽ thất nghiệp vào mùa đông vì ít ai có nhu cầu đi).

- Thất nghiệp theo chu kỳ (hay “cyclical unemployment”) là mức thất nghiệp tương ứng với từng giai đoạn trong chu kỳ kinh tế. Nguyên nhân sinh ra loại thất nghiệp này là do trạng thái tiền lương cứng nhắc. Nó là dạng thất nghiệp không tồn tại vĩnh viễn, sẽ biến mất nếu có đủ điều kiện tiên quyết.

- Thất nghiệp theo lý thuyết cổ điển (Classical Unemployment): thất nghiệp xảy ra là do mức lương tối thiểu được quy định cao hơn mức lương do quy luật cung-cầu trên thị trường quy định.

\section{Thực trang tình hình thất nghiệp nước ta trước và trong bối cảnh Covid19}

- Trước khi Covid 19 bùng nổ: Thất nghiệp vẫn luôn là vấn đề nan giải kéo dài( kể cả ở các nước phát triển): 
- Năm 2018, tỷ lệ thất nghiệp chung cả nước là 2,0\%, trong đó tỷ lệ thất nghiệp khu vực thành thị là $2,95 \%$; khu vực nông thôn là $1,55 \%$.

- Năm 2019, tỷ lệ thất nghiệp trong độ tuổi lao động là $2,17 \%$, trong đó ở khu vực thành thị là $3,11 \%$, khu vực nông thôn là $1,69 \%$.

- Khi đại dịch Covid 19 bùng nổ: Đại dịch Covit-19 xuất hiện tại Việt Nam đã ảnh hưởng trực tiếp đến tình hình lao động và việc làm trong tất cả các ngành và tại mọi miền trong nước từ nông thôn đến thành thị. Trong đó ảnh hưởng rõ rệt nhất là vào quý II năm 2020 khi tình hình diễn biến phức tạp, nhiều ca lây nhiễm nguy hiểm trong cộng đồng và đặc biệt là việc áp dụng quy định giãn cách toàn xã hội càng làm cho tỷ lệ thất nghiệp tăng cao. Nền kinh tế bị ngưng trệ, nhiều doanh nghiệp phải cho lao động ngừng, giãn hoặc nghỉ việc .Điều này làm cho tỷ lệ thất nghiệp trong độ tuổi lao động tăng kỷ lục trong vòng 5 năm gần đây cùng với đó là việc nhiều lao động rời bỏ thị trường lao động là điều dễ hiểu.

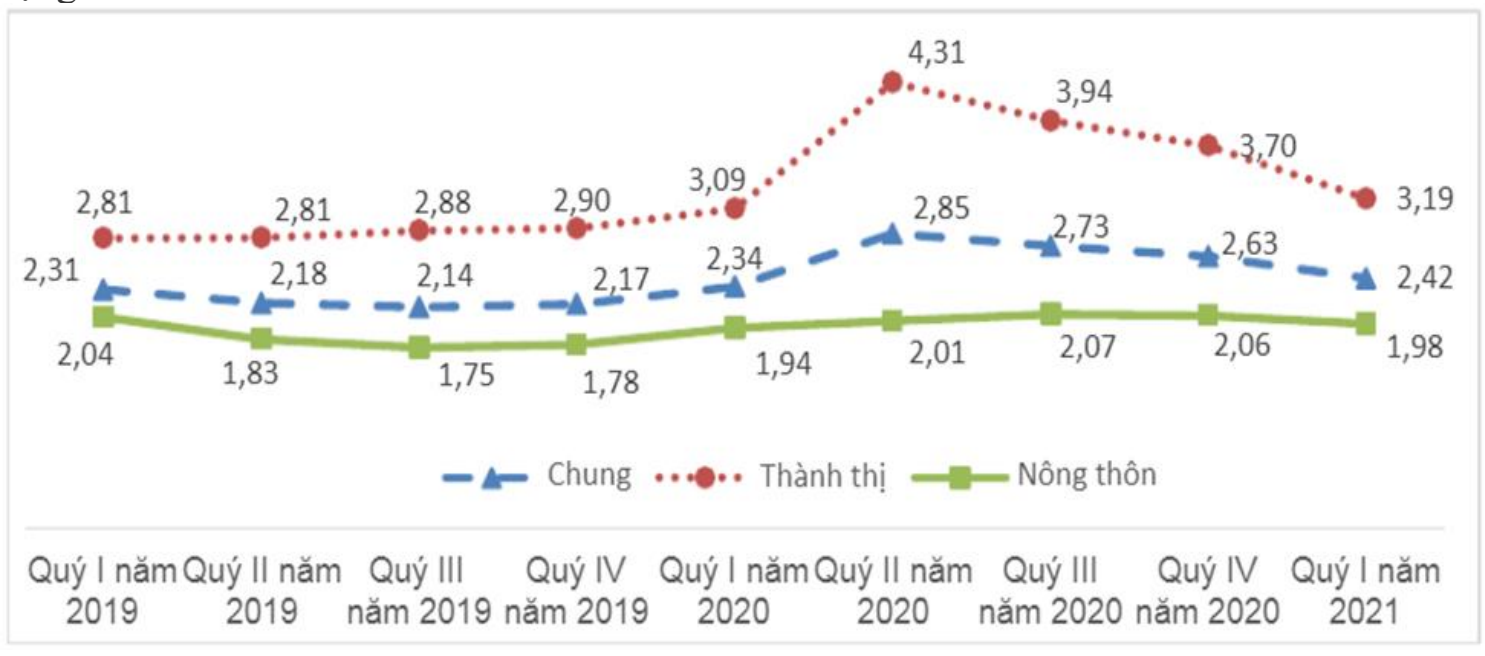

Hình 1. Tỷ lệ thất nghiệp trong độ tuổi lao động các quý giai đoạn 2019-2021 ở thành thị và nông thôn. Nguồn: Thời báo ngân hàng.

https://thoibaonganhang.vn/quy-i2021-van-con-91-trieu-lao-dong-bi-anh-huong-tieu-cuc-boicovid-19-113663.html

Năm 2020:

1. Quý I năm 2020:

Dịch Covid-19 xuất hiện tại Việt Nam tủ̉ cuối tháng 1 năm 2020 đến nay đã ảnh huởng trụcc tiếp đến việc tham gia thị truờng lao động của ngườ lao động. Thất nghiệp tăng lên, tỷ lệ thiếu việc làm của lao động trong độ tuổi ở mức cao nhất trong vòng 5 năm gần đây.

Số người thất nghiệp trong độ tuổi lao động quý I năm 2020 là gần 1,1 triệu người, tăng 26,1 nghìn người so với quý trước và tăng 26,8 nghìn người so với cùng kỳ năm trước. Tỷ lệ thất nghiệp trong độ tuổi lao động quý I năm 2020 là $2,22 \%$, tăng 0,07 điểm phần trăm so với quý trước và tăng 0,05 điểm phần trăm so với cùng kỳ năm trước. Tỷ lệ thất nghiệp trong độ tuổi của khu vực 
thành thị là $3,18 \%$, tăng 0,08 điểm phần trăm so với quý trước và cùng kỳ năm trước; tỷ lệ này của khu vực nông thôn là $1,73 \%$, tăng 0,06 điểm phần trăm so với quý trước và tăng 0,03 điểm phần trăm so với cùng kỳ năm trước.

Số thanh niên (từ 15 đến 24 tuổi) thất nghiệp ước khoảng 492,9 nghìn người. chiếm 44,1\% tổng số người thất nghiệp. Tỷ lệ thất nghiệp của thanh niên trong quý I năm 2020 ước là $7,0 \%$, tăng 0,5 điểm phần trăm so với quý trước và tăng 0,56 điểm phần trăm so với cùng kỳ năm trước. Tỷ lệ thất nghiệp thanh niên cao gấp 5,4 lần so với tỷ lệ thất nghiệp của dân số trưởng thành (những người từ 25 tuổi trở lên).

2. Quý II năm 2020:

Việc làm của người lao động ảnh hưởng rõ rệt nhất vào quý II năm 2020 khi tình hình dịch Covid-19 diễn biến phức tạp, nhiều ca lây nhiễm trong cộng đồng xuất hiện và đặc biệt là việc áp dụng các quy định về giãn cách xã hội. Tỷ lệ thất nghiệp đạt cao nhất trong vòng 10 năm qua.

Số người thất nghiệp trong độ tuổi lao động quý II là gần 1,3 triệu người, tăng 192,8 nghìn người so với quý trước và tăng 221 nghìn người so với cùng kỳ năm trước. Tỷ lệ thất nghiệp trong độ tuổi lao động quý II năm 2020 là $2,73 \%$, tăng 0,51 phần trăm so với quý trước và tăng 0,57 điểm phần trăm so với cùng kỳ năm trước. Tỷ lệ thất nghiệp trong độ tuồi của khu vực thành thị là $4,46 \%$, tăng 1,28 điểm phần trăm so với quý trước và tăng 1,36 điểm phần trăm so với cùng kỳ năm trước; đây là quý có tỷ lệ thất nghiệp trong độ tuổi của khu vực thành thị cao nhất trong vòng 10 năm qua.

Số thanh niên (từ 15 đến 24 tuổi) thất nghiệp trong quý II năm 2020 khoảng 410,3 nghìn người, chiếm 30,7\% tổng số người thất nghiệp. Tỷ lệ thất nghiệp của thanh niên trong quý II năm 2020 là $6.98 \%$, tương đương so với quý trước và tăng 0,3 điểm phần trăm so với cùng kỳ năm trước. Tỷ lệ thất nghiệp thanh niên trong quý II tăng do ảnh hưởng chung của dịch Covid-19.

Tỷ lệ thất nghiệp trong độ tuổi lao động của nhóm lao động có trình độ chuyên môn kỹ thuật từ trung cấp trở lên quý II năm 2020 giảm so với quý trước và tăng so với cùng kỳ năm trước. Trong khi đó, tỷ lệ thất nghiệp trong độ tuổi quý II năm 2020 của nhóm lao động có trình độ chuyên môn kỹ thuật thấp (sơ cấp) hoặc không có trình độ chuyên môn kỹ thuật đều tăng so với quý trước và so với cùng kỳ năm trước. Điều này cho thấy khi nền kinh tế gặp cú sốc, lao động có trình độ thấp hoặc không có trình độ gặp nhiều khó khăn hơn về cơ hội việc làm so với lao động có trình độ chuyên môn kỹ thuật bậc trung và bậc cao. 


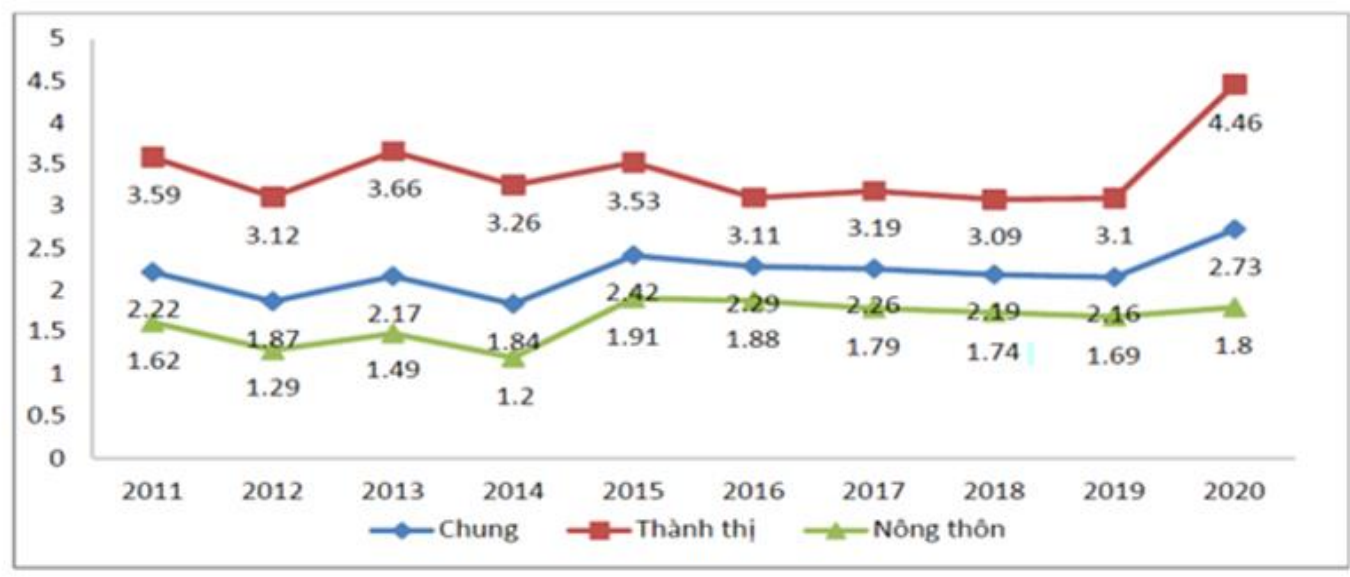

\section{Hình 2. Tỷ lệ thất nghiệp trong độ tuổi lao động quý II các năm giai đoạn 2011-2020 chia theo thành thị, nông thôn. Nguồn: Vietnambiz.}

\section{https://vietnambiz.vn/ti-le-that-nghiep-tai-viet-nam-cao-nhat-trong-10-nam-qua- $\underline{2020071023171888 . h t m}$}

\section{Quý III năm 2020:}

Sau khi nền kinh tế toàn cầu cũng nhur Việt Nam gần nhu chạm đáy vào quý 2 thì đến quý 3 2020 đã có một chút dấu hiệu khả quan hơn. Số người thất nghiệp cũng như tỷ lệ thất nghiệp đã giảm nhẹ so với quý trước tuy nhiên vẫn ở múcc cao nhất so với cùng kỳ các năm trước

Số người thất nghiệp trong độ tuổi lao động quý III năm 2020 là hơn 1,2 triệu người, giảm 63,0 nghìn người so với quý trước và tăng 148,2 nghìn người so với cùng kỳ năm trước. Tỷ lệ thất nghiệp trong độ tuổi lao động quý III năm 2020 là 2,50\%, giảm 0,23 điểm phần trăm so với quý trước và tăng 0,33 điểm phần trăm so với cùng kỳ năm trước. Tỷ lệ này ở khu vực thành thị là $4,0 \%$, giảm 0,46 điểm phần trăm so với quý trước và tăng 0,89 điểm phần trăm so với cùng kỳ năm trước.

Số thanh niên (từ 15 đến 24 tuổi) thất nghiệp trong Quý III năm 2020 khoảng 410,3 nghìn người, chiếm 30,7\% tổng số người thất nghiệp. Tỷ lệ thất nghiệp của thanh niên trong Quý III năm 2020 là $6,98 \%$, tương đương so với quý trước và tăng 0,3 điểm phần trăm so với cùng kỳ năm trước. Tỷ lệ thất nghiệp thanh niên trong Quý III tăng do ảnh hưởng chung của dịch Covid-19. 


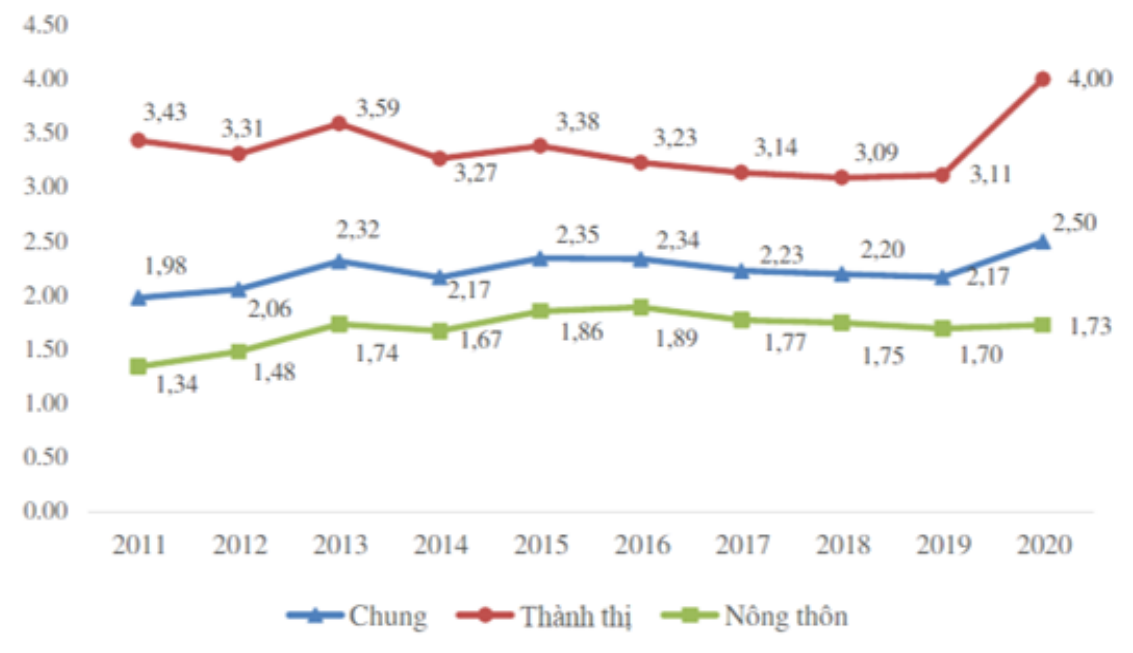

Hình 3. Tỷ lệ thất nghiệp trong độ tuổi lao động quý III các năm giai đoạn 2011-2020 chia theo thành thị và nông thôn. Nguồn: Thời báo ngân hàng.

https://thoibaonganhang.vn/ca-nuoc-co-318-trieu-lao-dong-that-nghiep-giam-thu-nhap-vi-covid19-107174.html

4. Quý IV năm 2020:

Tình hình lao động, việc làm quý này có nhiều chuyển biến tích cực khi tỷ lệ thất nghiệp trong độ tuổi lao động của khu vục thành thị tiếp tục giảm so với quý III nhung vẫn ở mức cao nhẩt so với cùng kỳ các năm giai đoạn 2011-2020.

Số người thất nghiệp trong độ tuổi lao động quý IV năm 2020 là gần 1,2 triệu người, giảm 60,1 nghìn người so với quý trước và tăng 136,8 nghìn người so với cùng kỳ năm trước. Tỷ lệ thất nghiệp trong độ tuổi lao động quý IV năm 2020 là $2,37 \%$, giảm 0,13 điểm phần trăm so với quý trước và tăng 0,33 điểm phần trăm so với cùng kỳ năm trước. Tỷ lệ này ở khu vực thành thị là $3,68 \%$, giảm 0,32 điểm phần trăm so với quý trước và tăng 0,78 điểm phần trăm so với cùng kỳ năm trước. Đại dịch Covid-19 đã làm tỷ lệ thất nghiệp của lao động trong độ tuổi khu vực thành thị quý IV năm 2020 cao nhất so với cùng kỳ trong vòng 10 năm qua.

Số thanh niên (từ 15 đến 24 tuổi) thất nghiệp trong Quý IV năm 2020 khoảng 410,9 nghìn người, chiếm $34,4 \%$ tổng số người thất nghiệp. Tỷ lệ thất nghiệp của thanh niên trong Quý IV năm 2020 là $7.05 \%$, tương đương so với quý trước. Tỷ lệ thất nghiệp của thanh niên khu vực thành thị là $10,83 \%$, khu vực nông thôn là 5,54\%. 


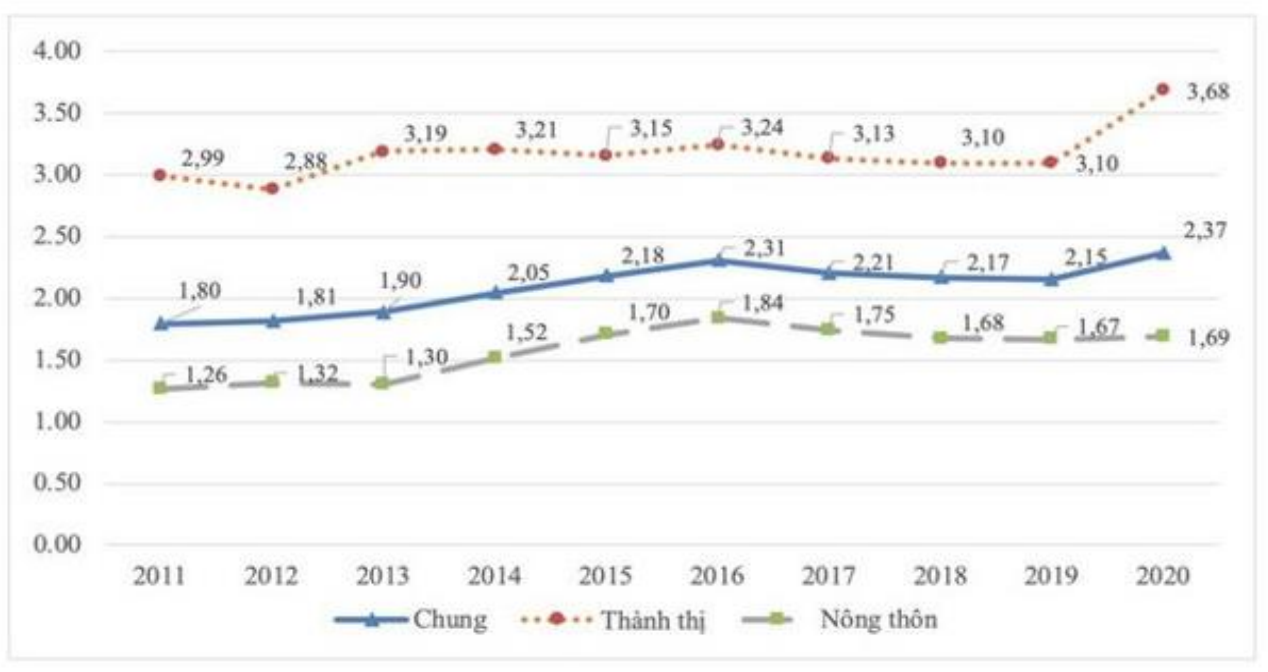

Hình 4. Tỷ lệ thất nghiệp trong độ tuổi lao động quý IV các giai đoạn 2011-2020 chia theo thành thị và nông thôn. Nguồn: Đầu tư chứng khoán.

\section{https://tinnhanhchungkhoan.vn/ty-le-that-nghiep-tai-thanh-thi-quy-iv-2020-o-muc-cao-nhat-so- voi-cung-ky-trong-10-nam-qua-post259205.html}

\section{Năm 2021:}

1. Quý I năm 2021:

Trong quý I năm 2021, cả nước vẫn còn 9,1 triệu người tù̀ 15 tuổi trở lên bị ảnh hưởng tiêu cục bởi dịch COVID-19 trong đó nam giới chiếm 51,0\% và số người trong độ tuổi từ 25 đến 54 chiếm gần hai phần ba. Trong tổng số 9,1 triệu người bị tác động tiêu cực bởi đại dịch COVID-19, có 540 nghìn người bị mất việc, 2,8 triệu người phải tạm nghỉ/tạm ngừng sản xuất kinh doanh; 3,1 triệu người cho biết họ bị cắt giảm giờ làm hoặc buộc phải nghỉ giãn việc, nghỉ luân phiên và 6,5 triệu lao động báo cáo họ bị giảm thu nhập. Xét theo 3 khu vực, khu vực ít chịu tác động nhất của đại dịch là khu vực nông, lâm nghiệp và thủy sản với 7,5\% lao động cho biết chịu tác động tiêu cực của đại dịch. Đứng thứ hai là khu vực công nghiệp và xây dựng với 16,5\% lao động bị ảnh hưởng. Lao động trong khu vực dịch vụ chịu ảnh hưởng nặng nề nhất, chiếm tỷ lệ 20,4\%.

Dịch Covid-19 bùng phát lần thứ ba ngay trước và trong dịp Tết nguyên đán làm tăng đáng kể số lao động thiếu việc làm so với quý truơớc và cùng kỳ năm truớc. Số người thiếu việc làm trong độ tuổi lao động quý I năm 2021 là 971,4 nghìn người; tăng 143,2 nghìn người so với quý trước và tăng 78,7 nghìn người so với cùng kỳ năm trước. Tỷ lệ thiếu việc làm của lao động trong độ tuổi quý I năm 2021 là $2,20 \%$; tăng 0,38 phần trăm so với quý trước và tăng 0,22 phần trăm so với cùng kỳ năm trước. 


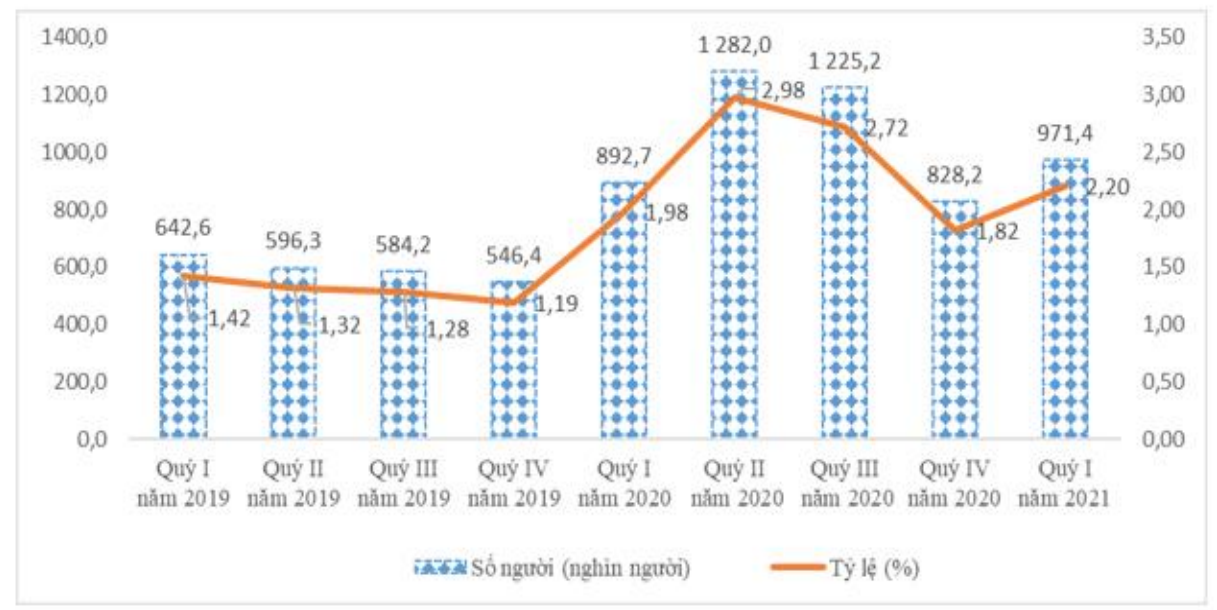

Hình 5. Số người, tỷ lệ thất nghiệp các quý trong năm 2019-2021. Nguồn: Tổng cục thống kê.

https://www.gso.gov.vn/du-lieu-va-so-lieu-thong-ke/2021/04/thong-bao-cao-chi-tinh-hinh-laodong-viec-lam-quy-i-2021/

2. Quý II năm 2021:

Thị truờng lao động Việt Nam đã bị ảnh hưởng do sụ bùng phát lần thứ 3 và thứ 4 của đai dịch Covid-19. Tình hình lao động việc làm quý II cho thấy thị truờng lao động chua thấy dấu hiệu khả quan với số nguoòi có việc làm giảm so với quý trước, tỷ lệ thất nghiệp và thiếu việc làm tăng so với quý truớc. Tỷ lệ lao động có việc làm phi chính thức tăng so với cùng kỳ năm truớc.

Số người thất nghiệp trong độ tuổi lao động quý II năm 2021 là gần 1,2 triệu người, tăng 87,1 nghìn người so với quý trước và giảm 82,1 nghìn người so với cùng kỳ năm trước. Tỷ lệ thất nghiệp trong độ tuổi lao động quý II năm 2021 là 2,62\%, tăng 0,2 điểm phần trăm so với quý trước và giảm 0,23 điểm phần trăm so với cùng kỳ năm trước. Tỷ lệ thất nghiệp trong độ tuổi của khu vực thành thị là $3,36 \%$, tăng 0,17 điểm phần trăm so với quý trước và giảm 0,95 điểm phần trăm so với cùng kỳ năm trước.

Số thanh niên từ 15-24 tuổi thất nghiệp trong quý II năm 2021 là 389,8 nghìn người, chiếm 31,8\% tổng số người thất nghiệp. Tỷ lệ thất nghiệp của thanh niên quý II năm 2021 là 7,47\%, tăng 0,03 điểm phần trăm so với quý trước và giảm 0,13 điểm phần trăm so với cùng kỳ năm trước. Tỷ lệ thất nghiệp của thanh niên khu vực thành thị là 9,57\%, cao hơn 3,11 điểm phần trăm so với khu vực nông thôn.

3. Quý III năm 2021:

Trong quý III và 9 tháng năm 2021, diễn biến phức tạp của dịch Covid-19 lần thứ tư tại nhiều địa phương, đặc biệt tại các tỉnh, thành phố trọng điểm kinh tế đã khiến cho tình hình lao động việc làm quý III năm 2021 tồi tệ hơn. Số người có việc làm giảm sâu so với quý truớc và cùng kỳ năm trước, tỷ lệ thất nghiệp và thiếu việc làm tăng lên mức cao nhất chưa tùng thấy. Thu 
nhập bình quân tháng của ngưò̀i lao động sụt giảm nghiêm trọng so với quý trước và cùng kỳ năm trước.

Số người thất nghiệp trong độ tuổi lao động quý III năm 2021 là hơn 1,7 triệu người, tăng 532,2 nghìn người so với quý trước và tăng 449,6 nghìn người so với cùng kỳ năm trước. Tỷ lệ thất nghiệp trong độ tuổi lao động quý III năm 2021 là 3,98\%, tăng 1,36 điểm phần trăm so với quý trước và tăng 1,25 điểm phần trăm so với cùng kỳ năm trước. Diễn biến phức tạp của dịch Covid19 lần thứ tư và thời gian giãn cách xã hội kéo dài ở nhiều địa phương đã đẩy tỷ lệ thất nghiệp quý III năm 2021 vượt xa con số $2 \%$ như thường thấy. Tỷ lệ thất nghiệp trong độ tuổi của khu vực thành thị là $5,54 \%$, tăng 2,18 điểm phần trăm so với quý trước và tăng 1,60 điểm phần trăm so với cùng kỳ năm trước.

Tỷ lệ thất nghiệp của thanh niên 15-24 tuổi quý III năm 2021 là 8,89\%, tăng 1,42 điểm phần trăm so với quý trước và tăng 0,75 điểm phần trăm so với cùng kỳ năm trước. Tỷ lệ thất nghiệp của thanh niên khu vực thành thị là $12,71 \%$, cao hơn 5,56 điểm phần trăm so với khu vực nông thôn.

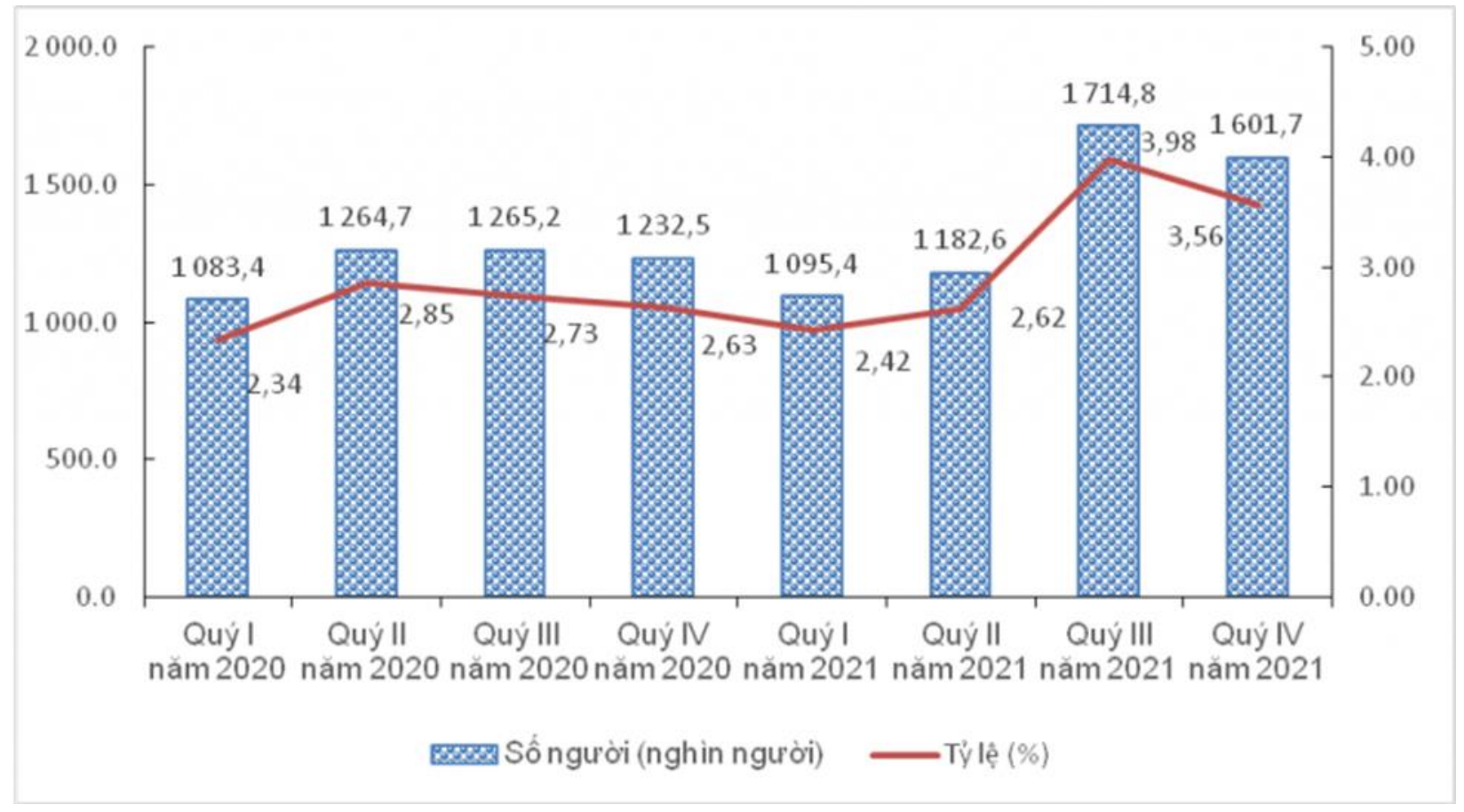

Hình 6. Số người và tỷ lệ thất nghiệp trong độ tuổi lao động các quý năm 2020 và 2021. Nguồn: Đầu tư chứng khoán.

https://tinnhanhchungkhoan.vn/ty-le-that-nghiep-va-thieu-viec-lam-trong-quy-iii-2021-tang-lenmuc-cao-nhat-chua-tung-thay-post282221.html

4. Quý IV năm 2021:

Cùng với chính sách thích ứng linh hoạt trong phòng chống dịch để khôi phục kinh tế, thị trường lao động quý IV bắt đầu có dấu hiệu phục hồi. Lục luộng lao động, số người có việc làm quý IV năm 2021 tăng so với quý truớc và giảm so với cùng kỳ năm trước. Tỷ lệ thất nghiệp 
và thiếu việc làm giảm so với quý trước và tăng so với cùng kỳ năm trước. Tuy nhiên, tính chung cả năm 2021, diê̂n biến phức tạp và kéo dài của đọt dịch Covid-19 lần thứ tư đã khiến tình hình lao động việc làm năm 2021 gặp nhiều khó khăn hơn so với năm 2020, lực luợng lao động, số người có việc làm giảm; tỷ lệ thiếu việc làm và thất nghiệp tăng so với năm trước.

Số người thất nghiệp trong độ tuổi lao động quý IV năm 2021 là hơn 1,6 triệu người, giảm 113,1 nghìn người so với quý trước và tăng 369,2 nghìn người so với cùng kỳ năm trước. Tỷ lệ thất nghiệp trong độ tuổi lao động quý IV năm 2021 là 3,56\%, giảm 0,42 điểm phần trăm so với quý trước và tăng 0,93 điểm phần trăm so với cùng kỳ năm trước. Tỷ lệ thất nghiệp trong độ tuổi của khu vực thành thị là $5,09 \%$, giảm 0,45 điểm phần trăm so với quý trước và tăng 1,39 điểm phần trăm so với cùng kỳ năm trước.

\section{BẢNG SỐ NGƯờI THẤT NGHIỆP VÀ TỶ LỆ THẤT NGHIỆP NĂM 2019, 2020 VÀ 2021.}

\begin{tabular}{|c|c|c|c|}
\hline & Năm 2019 & $\begin{array}{l}\text { Năm } \\
2020\end{array}$ & Năm 2021 \\
\hline - Số người thất nghiệp (nghìn người) & 1108,2 & 1234,9 & 1400 \\
\hline - Số thanh niên (15-24t) thất nghiệp & 466,3 & 431,7 & 447,7 \\
\hline $\begin{array}{l}\text { Tỷ lệ thất nghiệp trong độ tuổi lao động (\%) } \\
\text { Chia theo khu vực: }\end{array}$ & 2,17 & 2,68 & 3,22 \\
\hline - Thành thị & 3,11 & 3,38 & 4,42 \\
\hline - Nông thôn & 1,69 & 1,75 & 2,48 \\
\hline Chia theo giới tính: & & & \\
\hline - Nam & 2,09 & 2,01 & Chưa có \\
\hline - Nữ & 2,26 & 3.04 & Chưa có \\
\hline $\begin{array}{l}\text { Tỷ lệ thất nghiệp của thanh niên (\%) } \\
\text { Chia theo khu vực: }\end{array}$ & 6,51 & 7,96 & 8,48 \\
\hline - Thành thị & 10,40 & 10,58 & 11,91 \\
\hline - Nông thôn & 4,89 & 5,45 & 5.41 \\
\hline Chia theo giới tính: & & & \\
\hline - Nam & 6,49 & 6,02 & Chưa có \\
\hline - Nữ & 6,54 & 8,53 & Chưa có \\
\hline
\end{tabular}




\section{Kết luận.}

Đại dịch Covid-19 đã gây ra nhiều xáo trộn trên thị trường lao động Việt Nam, với hàng triệu người lao động bị ảnh hưởng tiêu cực bởi thất nghiệp, phải nghỉ phép/ luân chuyển, giảm giờ làm, giảm thu nhập, v.v. Đây là lần đầu tiên trong 10 năm qua, nền kinh tế Việt Nam bị sụt giảm nghiêm trọng về số lượng người tham gia thị trường lao động và việc làm. Thu nhập bình quân của người lao động cũng bị thâm hụt. Tỷ lệ thất nghiệp, thiếu việc làm và tỷ lệ lao động làm việc phi chính thức đều tăng mạnh so với xu hướng giảm của những năm gần đây. Tuy nhiên, với sự quyết tâm của chính quyền và sự chung sức, đồng lòng của người dân, tình hình lao động, việc làm trong những tháng cuối năm 2020 đã được cải thiện rõ rệt. Thành tựu này không chỉ giúp đạt được mục tiêu phòng chống dịch mà còn góp phần bảo vệ sự tăng trưởng và phát triển kinh tế của đất nước. Kết quả của Điều tra Lao động và Việc làm cho quý 2020 cho thấy sự bùng phát của Covid-19 đã có tác động tiêu cực đến sự tham gia của người lao động vào thị trường lao động và tạo thu nhập từ việc làm. Với diễn biến phức tạp của dịch Covid-19, đặc biệt là các biến thể mới của virus hiện đang lây lan nhanh, ảnh hưởng của dịch đến đời sống và sản xuất trong thời gian tới là điều khó lường. Để chủ động ứng phó và thích ứng với sự phát triển của dịch, vừa khống chế được dịch, vừa thúc đẩy sản xuất và hoạt động, các biện pháp cần phải được thực hiện đồng thời, lập tức. Cách tiếp cận chung là cần sử dụng hệ xử lý sáng tạo $3 \mathrm{D}$, coi trọng khoa học công nghệ (Vuong, 2018) và đẩy mạnh công tác truyền thông, chuyên gia, hợp tác giữa các bên liên quan để chung tay giải quyết vấn đề (Vuong, Q.H., 2022; Vuong \& Napier, 2014). Phần II sẽ là những nhận thức cũng như là giải pháp cải thiện thực trạng thất nghiệp ở Việt Nam trong thời kỳ dịch bệnh đang diễn biến ngay càng phức tạp, khó lường.

\section{TÀI LIẸU THAM KHẢO}

La, V. P. et al. (2020). Policy response, social media and science journalism for the sustainability of the public health system amid the COVID-19 outbreak: The vietnam lessons. Sustainability (Switzerland), 12(7). https://doi.org/10.3390/su12072931

Vuong, Q.H., et al. (2022). Covid-19 vaccines production and societal immunization under the serendipity-mindsponge-3D knowledge management theory and conceptual framework. Humanities \& Social Sciences Communications, 9, 22. Retrieved from: https://www.nature.com/articles/s41599-022-01034-6

Vuong, Q. H. (2018). The (ir)rational consideration of the cost of science in transition economies. Nature Human Behaviour, 2(1), 5. https://doi.org/10.1038/s41562-017-0281-4

Vuong, Q. H., \& Napier, N. K. (2014). Making creativity: the value of multiple filters in the innovation process. International Journal of Transitions and Innovation Systems, 3(4), 294327. https://doi.org/10.1504/ijtis.2014.068306

Bộ kế hoạch và đầu tư Tổng cục Thống kê. (2020). BÁO CÁO ĐIỂU TRA LAO ĐỘNG VIẸC $L A M M Q U Y ́ 1$ NĂM 2020. Tổng Cục Thống Kê. https://www.gso.gov.vn/wpcontent/uploads/2020/08/BC-LDVL-Quy-1.2020_finalf.pdf

Gilpatrick, E. (1996). On the Classification of Unemployment: A View of the StructuralInadequate Demand Debate. SAGE Journals. 
https://doi.org/https://doi.org/10.1177\%2F001979396601900203

Ngọc, N. (2021, August 18). Thất nghiệp là gì? Có bao nhiêu loại thất nghiệp trong kinh tế vĩ $m \hat{o}$ ? News.Timviec.Com.Vn. https://news.timviec.com.vn/that-nghiep-la-gi-cach-phan-loaiva-tac-dong-cua-no-den-nen-kinh-te-50061.html

Tổng cục thống kê. (2020a). THÔNG CÁO BÁO CHÍ TİNH HÌNH LAO ĐÔNNG VIẸC LÀM QUÝ II VÀ 6 THÁNG ĐÂU NĂM 2020 (pp. 1-10). Tổng cục thống kê.

Tổng cục thống kê. (2020b). THÔNG CÁO BÁO CHÍ TÌNH HÌNH LAO ĐỘNG VIẸC LÀM QUÝ III VÀ 9 THÁNG NĂM 2020 (pp. 1-10). Tổng cục thống kê.

Tổng cục thống kê. (2020c, October 7). Thông cáo báo chí Tình hình Lao động làm việc Qúy I và 4 tháng đầu năm 2020. Tổng Cục Thống Kê.

http://thongketiengiang.gov.vn/Info.aspx?id=1072020121943439

Tổng cục thống kê. (2021a). BÁO CÁO TÁC ĐÔNNG CỦA DICH COVID-19 ĐẾN TÌNH HÌNH LAO ĐỘNG, VIẸC LÀM QUÝIV VÀ NĂM 2020. Tổng Cục Thống Kê.

https://www.gso.gov.vn/du-lieu-va-so-lieu-thong-ke/2021/01/bao-cao-tac-dong-cua-dichcovid-19-den-tinh-hinh-lao-dong-viec-lam-quy-iv-va-nam-2020/

Tổng cục thống kê. (2021b). TÁC ĐỘNG CỦA DICH COVID-19 ĐẾN TĂNG TRƯỞNG CÁC KHU VUUC KINH TÉ QUÝ III NĂM 2021. Tổng Cục Thống Kê.

https://www.gso.gov.vn/du-lieu-va-so-lieu-thong-ke/2021/10/tac-dong-cua-dich-covid-19den-tang-truong-cac-khu-vuc-kinh-te-quy-iii-nam-2021/

Tổng cục thống kê. (2021c). THÔNG BÁO CÁO CHÍ TİNH HÌNH LAO ĐỘNG, VIẸC LÀM QUÝ I/2021 (pp. 1-9). Tổng cục thống kê.

Tổng cục thống kê. (2021d). THÔNG CÁO BÁO CHÍ TİNH HİNH LAO ĐỘNG VIẸC LÀM QUÝ II VÀ 6 THÁNG ĐÂUU NĂM 2021. Tổng Cục Thống Kê. https://www.gso.gov.vn/du-lieu-vaso-lieu-thong-ke/2021/07/thong-cao-bao-chi-tinh-hinh-lao-dong-viec-lam-quy-ii-va-6thang-dau-nam-2021/

Tổng cục thống kê. (2021e). THÔNG CÁO BÁO CHÍ TİNH HÌNH LAO ĐÔNNG VIẸC LÀM QUÝ III VÀ 9 THÁNG NĂM 2021. Tổng Cục Thống Kê. https://www.gso.gov.vn/du-lieu-va-solieu-thong-ke/2021/10/thong-cao-bao-chi-tinh-hinh-lao-dong-viec-lam-quy-iii-va-9-thangnam-2021/

Tổng cục thống kê. (2021f, January 6). BÁO CÁO TÁC ĐỘNG CỦA DỊCH COVID-19 ĐẾN TİNH HİNH LAO ĐỘNG, LÄM VIẸC QUÝ IV VÀ NĂM 2020. Tổng Cục Thống Kê. https://www.gso.gov.vn/du-lieu-va-so-lieu-thong-ke/2021/01/bao-cao-tac-dong-cua-dichcovid-19-den-tinh-hinh-lao-dong-viec-lam-quy-iv-va-nam-2020/

Tổng cục thống kê. (2022). THÔNG CÁO BÁO CHÍ TİNH HìNH LAO ĐÔNGG VIẸC LÀM QUÝ IV NĂM 2021 VÀ CHİ SỐ PHÁT TRIẾN CON NGƯỜI VIẸT NAM 2016-2020. Tổng Cục Thống Kê. https://www.gso.gov.vn/du-lieu-va-so-lieu-thong-ke/2022/01/thong-cao-bao-chitinh-hinh-lao-dong-viec-lam-quy-iv-nam-2021-va-chi-so-phat-trien-con-nguoi-viet-nam2016-2020/\#: :text=Tỷ lệ thất nghiệp trong,với cùng kỳ năm trước

Tổng cục thống kê Việt Nam. (2020). BÁO CÁO TÌNH HÌNH KINH TÉ - XÃ HỘI QUÝ II VÀ 6 THÁNG N $\breve{A M}$ 2020. Tổng Cục Thống Kê. https://www.gso.gov.vn/du-lieu-va-so-lieu- 
thong-ke/2020/06/bao-cao-tinh-hinh-kinh-te-xa-hoi-6-thang-dau-nam2020/?fbclid=IwAR36QeMZKB9DS8MRRaS1WlCFbOpQLLq5lvvx9T742vlfD2vTi3cSi0FDmg

Tổng cục thống kê Việt Nam. (2021). Báo cáo tình hình kinh tế - xã hội quý III và 9 tháng năm 2021. https://www.gso.gov.vn/du-lieu-va-so-lieu-thong-ke/2021/09/bao-cao-tinh-hinh-kinhte-xa-hoi-quy-iii-va-9-thang-nam-2021/\%0A 